formed so rigid a defence that examination was impossible. and left the hospital, the wound being entirely healed Pain above and a little to the right of the umbilicus was on Nov. 5th.

severe. The patient looked ill and anxious. The motions were normal. After the attack had subsided the stomach was more carefully examined and found to be dilated, reaching three-quarters of an inch below the umbilicus. A diagnosis of pyloric ulcer with perigastritis was made. 0n Oct. 12th the abdomen was opened between the linea semilunaris and the middle line. Many adhesions were

3. When pain and gastorrhagia or enterorrhagia are persistent and disabling.-Case 4 in my list is an admirable example of this form. The treatment of such cases is by the performance of gastro-enterostomy. The amount of food passing over the ulcer is reduced considerably (the greater part going by the new opening), and the rest so secured permits the healing of the ulcer.

Tabie II.-Chses of Chronic DuOdexal UlCER.

\begin{tabular}{|c|c|c|c|c|}
\hline 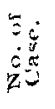 & Date. & $\begin{array}{l}\dot{x} \\
\dot{x}\end{array}$ & $\frac{c}{8 x}$ & Symptoms and rescription. \\
\hline 1 & $\begin{array}{l}\text { January } \\
1900 .\end{array}$ & F. & 41 & $\begin{array}{l}\text { At the age of } 16 \text { years the patient had had an } \\
\text { illness, attended with the vomiting of } \\
\text { blood, on one occasion in large quantity. } \\
\text { She had had pain after tood ever since, at } \\
\text { times better, at times worse. The diet had } \\
\text { been carefully and rigidly supervised. In } \\
\text { June, 1899, pain began to be much more } \\
\text { acute, and vomiting, which before had been } \\
\text { inconstant, now became frequent. Large } \\
\text { quantities (four pints) were vomited. On } \\
\text { examination of the abdomen a large contract- } \\
\text { ing stomach was seen. Nothing abnormal } \\
\text { was felt over the pylorus. }\end{array}$ \\
\hline 2 & $\begin{array}{c}\text { January } \\
1900 .\end{array}$ & II. & 55 & $\begin{array}{l}\text { Dyspepsia for } 10 \text { years; periorlic seizures of } \\
\text { copious vomiting at intervals of from } 24 \\
\text { hours to three weeks. }\end{array}$ \\
\hline & $\begin{array}{l}\text { Feh. 16th, } \\
1901 .\end{array}$ & F. & 31 & $\begin{array}{l}\text { For some years there were pain after food } \\
\text { and diarrhcea ; pain came on about half-an- } \\
\text { hour after food and lasted for three hours } \\
\text { or more; hrmatemesis. }\end{array}$ \\
\hline & $\begin{array}{l}\text { March 3rd, } \\
1901 .\end{array}$ & M. & 30 & $\begin{array}{l}\text { The patient was sent to me by Mr. G. Mill- } \\
\text { house and Mr. G. P. Anning with a diagnosis } \\
\text { of duodenal uIcer; symptoms had persisted } \\
\text { for five or six years. There were pain in the } \\
\text { epigastrium after meals and vomiting; had } \\
\text { attacks of faintness and prostration, } \\
\text { followed by meleena and anemia. }\end{array}$ \\
\hline
\end{tabular}

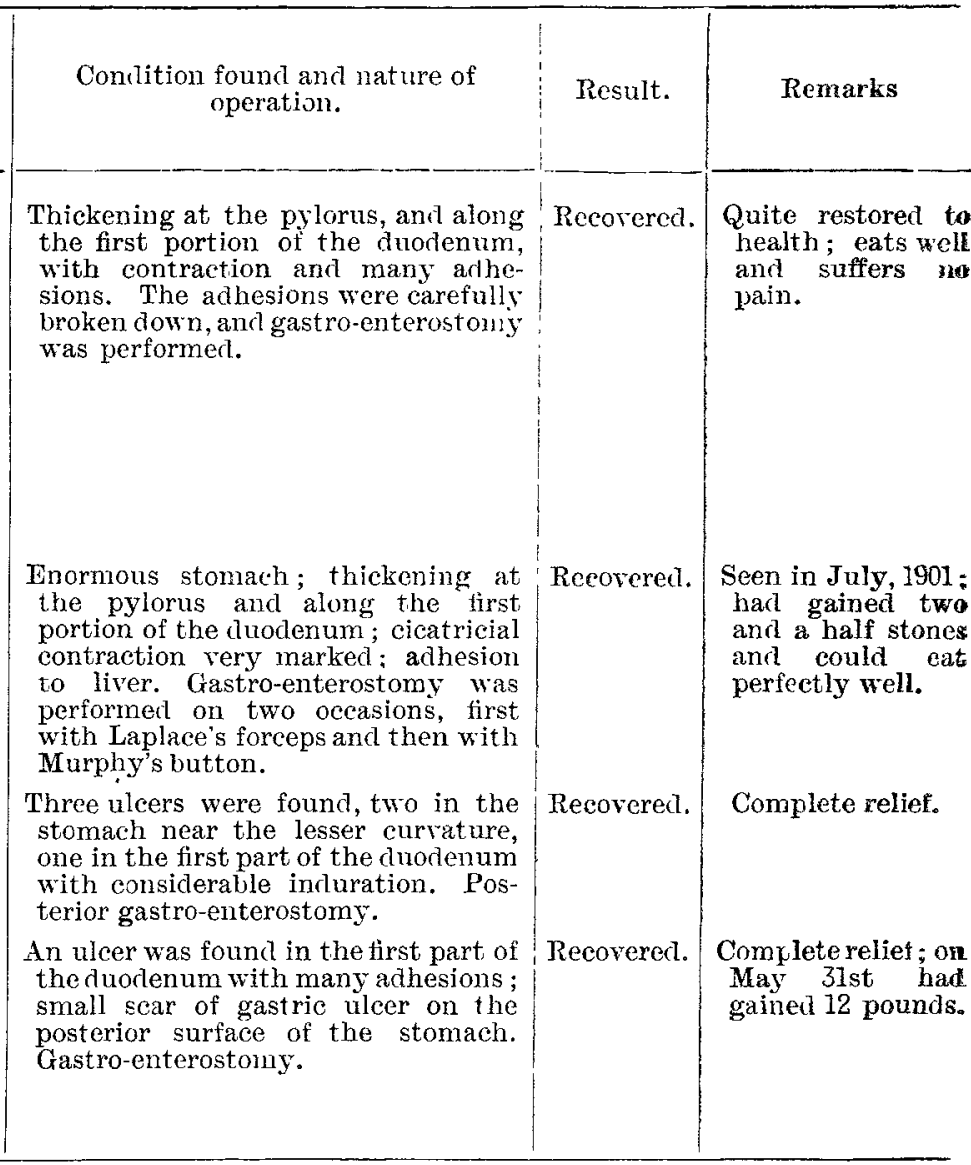

found around the pylorus, duodenum, and gall-bladder. On separating these an abscess cavity holding three ounces of pus was discovered. It lay between the liver and dnodenum. The duodenal wall was thickened and indurated and there was an ulcer at the junction of the first and second portions which had perforated and caused a localised peridrodenal abscess. The liver, gall-bladder, and biledncts were intact. A drainage-tube with a sterilised ganze wick was introduced. The patient did well
4. When cicatricial contraction and induration or periduodenitis are present. - In such cases the symptoms are those of dilated stomach and a diagnosis of pyloric narrowing will generally be made. Gastro-enterostomy will give complete relief. A case of ulcer, causing stenosis, in the fourth portion of the duodenum is related by Rewitzow. Gastroenterostomy was performed. My experience extends to four cases, the notes of which are given in Table II.

Leeds.

\section{EXPERIMENTAL HÆMOGLOBINURIA CAUSED BY A BACTERIAL TOXIN.}

By CHARLES TODD, M.D., D.P.H. CANTAB., ASSISTANT BACTERIOLOGIST, ANTITOXIN DEPARTMENT, JENNER INSIYTUTE OF PREVEN'IIVE MEDICINE.

\section{(Preliminary Communication.)}

IT is well known that the injection into the blood-stream of certain substances which have a solvent effect on the red hood corpuscles gives rise to the appearance of hæmoglobin in the urine. This has been described as the result of the injection of certain simple chemical bodies (e.g., distilled water, glycerine, \&c.), and of the sera of other animals. Since the discovery of tetanolysin by Ehrlich a series of hæmolysins has been described as produced by various organisms-e.g., bacillus pyocyaneus, ${ }^{1}$ staphylococcus aureus and albus, ${ }^{2}$ bacillus diphtheriæ, micrococcus tetragonus, streptococcus pyogenes, ${ }^{3}$ and bacillus typhosus, ${ }^{4}$ \&c.

${ }_{1}^{1}$ Bulloch and Hunter: Centralblatt fir Bakteriologie, 1960, Band ixriii., p. 865 .

eisser and Wechsherg : Zeitschrift fuir Hygiene, 1901.

\& E Luenau : Centralblatt fir Baktcriologie, 1901, Band xxx., p. 356. 16.1, Bant xxx., p. 405
These organisms, however, are all pathogenic for animals, and their hæmolytic action, which in most cases is comparatively feeble, is masked by other more obvious pathogenic effects. A more suitable organism for the study of experimental hæmoglobinuria is found in the bacillus megatherium, which, when grown in suitable media, gives rise to the formation of products which are very powerfully hremolytic for the corpuscles of certain animals without causing death or serious illness from other pathogenie effects.

The hæmolytic action of the bacillus was first observed in the course of some experiments with a sample of papain in powder. It was found that the powder contained a strongly hæmolytic bacillus which on isolation proved to be the bacillus megatherium. A culture of the same bacillus was obtained from hay infusion, and these two races, together with one of the bacillus megatherium (De Bary) obtained from Kral of Prague were used in the following experiments. These three, though showing slight cultural differences, appear to be all races of the same bacillus. Parallel experiments were done with the three races, which were grown in alkaline broth in Erlenmeyer flasks at $37^{\circ} \mathrm{C}$., and the hæmolytic power of the cultures was tested daily on a 5 per cent. suspension of guinea-pigs' washed corpuscles in 0.75 per cent. saline.

Formation of the hemolysin.-The formation of the hæmolysin, which is in the main extra-bac:llary, begins A $A 3$ 
under these circumstances between the second and third days, the amount rapidly rising to a maximum on the sixth or seventh day; after this it slowly decreases. The temperature exercises an important action, and so far the best results have been obtained at from $35^{\circ}$ to $37^{\circ} \mathrm{C}$. Oxygen is essential, and though some growth takes place anaerobically there is no formation of hæmolysin, hence a much stronger lysin was obtained by growing the bacillus in shallow layers of broth in Erlenmeyer flasks than in test tubes.

A somewhat high degree of alkalinity of the medium appears to favour the production of the lysin, and the best results were obtained with ordinary peptone beef bouillon, which was made just alkaline to litmus, and then normal caustic soda was added in the proportion of seven cubic centimetres per litre. Parallel experiments were made by growing the same bacillus (1) in six flasks of broth made just alkaline to litmus; and (2) in six flasks of the same broth with the addition of seven cubic centimetres of normal caustic soda per litre. After nine days in the incubator the cultures were filtered throngh a Pasteur-Chamberland filter and tested on guinea-pigs' corpuscles, with the result that the filtrate in the first case hrmolysed six times its volume, and the more alkaline filtrate 40 times its volume of the suspension, showing that the formation of the lysin was approximately seven times as great in the highly alkaline broth.

Action of the lysin on the corpuscles of various animals.The red blood corpuscles of different species show a very great difference in the extent to which they are affected by the lysin, those of the guinea-pig being found the most sensitive of the corpuscles tried, one cubic centimetre of the filtered culture completely hæmolysing about 50 cubic centimetres of a 5 per cent. suspension of these corpuscles in an hour at $37 \circ \mathrm{C}$. The corpuscles of man and of the monkey are also highly sensitive. The corpuscles of the sheep, goat, pig, and bullock are moderately sensitive, those of the dog, rat, rabbit, fowl, and sparrow are very slightly affected, and those of the donkey and horse are practically unaffected.

Nature of the lysin. - Megatheriolysin resembles the toxins of diphtheria and tetanus in being mainly extra-bacillary. even young cultures filtered through a Pasteur-Chamberland filter being strongly hamolytic. It is very unstable at ordinary temperatures, but much less so than tetanolysin according to Madsen's ${ }^{j}$ description of the latter. At $0^{\circ} \mathrm{O}$. it is comparatively stable. A filtered culture kept in the ice-safe for 14 days was found to be almost unaltered. but one kept at about $20^{\circ} \mathrm{O}$. for three weeks had gone down to one-eighth of its original strength. Heating to $56^{\circ} \mathrm{C}$. for 30 minutes completely destroys the hæmolytic action of filtered cultures. Heating for five minutes at $100^{\circ} \mathrm{C}$. does not entirely destroy the action of unfiltered cultures but very nearly so.

Existence of an anti-body in normal serum.-The antihamolytic action of normal serum towards a bacterial hæmolysin was first pointed out by Ehrlich ${ }^{6}$ in the case of tetanolysin, and later by Kraus and Clairmont ${ }^{7}$ and Neisser and Wechsberg ${ }^{5}$ for other bacterial lysins. In the case of megatheriolysin various normal sera exercise a considerable anti-hæmolytic action, both towards the corresponding corpuscles and also towards those of other animals; thus normal human serum protects human corpuscles against the lysin; the sera of the sheep and pig are strongly anti-hæmolytic towards their own corpuscles; donkey's serum has a marked action in protect. ing the corpuscles of the guinea-pig against the lysin, and this anti-hæmolytic power is increased by heating the serum for half an hour at from $63^{\circ}$ to $65^{\circ} \mathrm{C}$. No change takes place on heating for the same time at $60^{\circ} \mathrm{C}$. Thus in one experiment it was found that a tube containing two cubic centimetres of 5 per cent. suspension of guinea-pigs' corpuscles required 0.05 cubic centimetre of the filtered culture for complete hæmolysis. If, however, 0.2 cubic centimetre of normal donkey's serum was added to the suspension 0.50 cubic centimetre-i.e, ten times as much-of the filtered culture was necessary. and if the donkey's serum had been previously heated to $64^{\circ} \mathrm{C}$. for half an hour 0.90 cribic centimetre was required, so that the anti-hæmolytic action of the serum had been almost doubled by heating. The same phenomenon is observed in the case of sheep's serum and

5 Zeitschrift für Hygiene. 1899, Band xxxij.. p. 214.

7 Wiener Klinische Wochenschrift, 1898 子 Loc. eit. also of horse's serum, though in the latter case it is not so marked.

It is not easy to see any explanation of this increase in the anti-hæmolytic action of normal sera on heating, and it is possible that it is merely a physical effect depending on an alteration of the osmotic conditions, as the temperature of heating is so near the coagulation-point that the sera are quite viscid.

Immunisation of animals. - The subcutaneous injection of filtered cultures of the bacillus in guinea-pigs gives rise to a large local swelling with subsequent nccrosis, and after several injections the serum of the animal acquires powerful anti-hæmoiytic properties; but the guinea-pig is not a convenient animal for the production of an anti-serum, both on account of its small size and the tendency to local necroses. These necroses do not occur in the goat and the injections. appear to cause very slight inconvenience in this animal. Two goats were immunised with the filtered cultures. beginning with one cubic centimetre subcutaneously and gradually increasing the doses up to 100 cubic centimetres 10 days after the last injection the animals were bled anrl the serum was tested. In both cases it was found to be very strongly anti-hæmolytic. In one case one cubic centimetre of the serum completely neutralised 17 cubic centimetres of a filtered culture of the bacillus, this amount of the particular culture being enough to cause the complete hæmolysis of 1700 cubic centimetres of a 5 per cent. suspension of guinea-pigs' corpuscles in three hours at $37^{\circ} \mathrm{C}$ The animal from which this serum was obtained was immunised with cultures of the bacillus obtained from hay infusion, and its serum was found to neutralise the lysins formed by each of the three races of the bacillus used; thus confirming the view that these three bacilli-in spite of slight cultural differences-were all races of the bacillus megatherium. Having obtained a strongly anti-hæmolytic serum. the constitution of the hæmolysin was investigated by Ehrlich's method of partial neutralisation, and it was found that the results of these determinations when plotted yield "spectra "similar in character to those obtained in the case of diphtheria toxin, and more especially resembling those obtained by Madsen ${ }^{9}$ for tetanolysin.

Action of the filtered cultures on animals. - In guinea-pigs. when given subcutaneously, even in doses as large as 20 cubic centimetres, the filtered cultures do not produce death. but give rise to a large swelling with subsequent necrosis. The substance giving rise to this necrosis is destroyed by heating at $60^{\circ} \mathrm{C}$. for half an hour, but does not appear to be

Table showing Results of Intravenous Injection of Filterct. Cultures of the Bacillus Megatherium in Guinea-pigs.

\begin{tabular}{|c|c|c|c|}
\hline 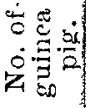 & $\begin{array}{l}\text { Dose of filtered } \\
\text { culture injected } \\
\text { intravenously. }\end{array}$ & Symptoms. & Result. \\
\hline 1 & $\begin{array}{l}1 \text { c.c. }+9 \text { c.c. } \\
\text { saline. }\end{array}$ & $\begin{array}{l}\text { Five hours later, hemoglobinuria. } \\
\text { There were no red blood corpuscles } \\
\text { in the urine. }\end{array}$ & Lived. \\
\hline 2 & $\begin{array}{l}2 \text { c.c. }+8 \text { c.c. } \\
\text { saline. }\end{array}$ & $\begin{array}{l}\text { Five hours later, hæmnglobinuria. } \\
\text { There were no red blood corpuscles } \\
\text { in the urine. }\end{array}$ & Lived. \\
\hline 3 & $\begin{array}{l}5 \text { c.c. }+5 \text { c.c. } \\
\text { saline. }\end{array}$ & $\begin{array}{l}\text { One and a half hours later, hæmo- } \\
\text { globinuria. Crystals of hæmo- } \\
\text { globin and a few blood corpuscles } \\
\text { were found. }\end{array}$ & Lived. \\
\hline 4 & $\begin{array}{l}8 \text { c.c. }+2 \text { c.c. } \\
\text { saline. }\end{array}$ & $\begin{array}{l}\text { Three hours later, hamoglobinuria. } \\
\text { Crystals of hamoglobin and many } \\
\text { blood corpuscles were present. }\end{array}$ & Liret. \\
\hline 5 & 10 c.c. & $\begin{array}{l}\text { Two hours later, hæmoglobinuria; } \\
\text { there were no blood corpuseles. } \\
\text { Three and a half hours later, } \\
\text { hæmoglobinuria; many blood cor- } \\
\text { puscles were present. }\end{array}$ & $\begin{array}{l}\text { D i e d } \\
\text { in } 12 \\
\text { hours. }\end{array}$ \\
\hline 6 & 10 c.c. & $\begin{array}{l}\text { Hæmoglobinuria, hæmaturia, and } \\
\text { epistaxis. }\end{array}$ & $\begin{array}{l}\text { D i e d } \\
\text { in } 10 \\
\text { hours. }\end{array}$ \\
\hline 7 & $\begin{array}{l}10 \text { c.c. }+0.5 \text { c.c. } \\
\text { anti-serum. }\end{array}$ & No symptoms. & Lired. \\
\hline 8 & $\begin{array}{l}10 \text { c.c. }+5 \text { c.c. } \\
\text { anti-serum.* }\end{array}$ & No symptoms. & Liven. \\
\hline
\end{tabular}

* In this case the anti-serum was given subcutaneously and 24 hours before the intravenous injection of the filtered culture.

The animals used were all approximately 500 grammes in weight. 
neutralised, at any rate completely, by the serum of immunised animals.

The action of the filtered cultures when given intrarenously in guinea-pigs is seen from the appended table. The results depend naturally upon the strength of the culture, bot with the lysin used in these experiments a dose of 10 cubic centimetres intravenously was usually fatal ; with smaller doses-from one cubic centimetre to eight cubic centimetres-the animals survived. A few hours after the injection the urine passed was a dark reddish-brown, often of the colour of stout, and gave the oxyhæmoglobin spectrum. If the urine was passed shortly after the injection, most commonly no red blood corpuscles were present, but these generally appeared later, and with large doses were found in the urine passed quite early. The hæmoglobin appears to be excreted mostly in the form of oxyhæmoglobin.

When mixed with a small amount of the anti-serum intravenous injections even of large quantities of the lysin produce no hæmoglobinuria, and if the animals receive a subcutaneous injection of the anti-serum the day before the intravenous injection of the lysin no hæmoglobinuria results, showing that the hæmolysis is brought about by a specific lysin and not by a simple chemical or physical action. In this connexion it is interesting to note that in the rabbit-the corpuscles of which are only very slightly affected by the lysis in vitro-large intravenous injections of the lysin produce no hæmoglobinuria.

The fact that a widely distributed organism, which has hitherto been regarded as practically non-pathogenic, is capable of forming products bringing about in susceptible animals such profound blood-changes is of the greatest interest, and although this bacillus may have no causal relation to any pathological condition in man or the lower animals, still the results obtained are suggestive in connexion with the pathology of such diseases as blackwater fever, paroxysmal hæmoglobinuria, and pernicious anæmia. Harrow.

\section{MOVEABLE OR FLOATING KIDNEY A CAUSE OF ACUTE AND CHRONIC PAINFUL DYSPEPSIA,}

\author{
WITH NOTES OF CASES.
}

BY ALEX. MACGREGOR, M.D. ABERD., M.R.C.P. LOND.,

PIISICIAN TO THE NORTH LONDON HOSPITAL FOR CONSUMPTION AND IISEASES OF THE CHEST.

Move_BLLE or floating kidney is by no means rare, yet it is frequently overlooked or apparently not suspected. If in the treatment of cases of chronic painful indigestion a systematic examination of the abdomen be made it not infrequently will be found, especially in women, that the cause of the dyspepsia is not in the stomach itself, but that the interference with the functions of that organ is due to the wanderings of a dislocated kidney. Except in those cases where the dislocation interferes with the functions of the kidney itself no symptom points directly to the nephroytosis. The kidney is not readily thought of as being the cause of an acute attack of jaundice with sickness and severe pain in the epigastrium, yet it has been known to give rise to such symptoms, and the first of the cases hereafter described is an example. Malignant disease of the stomach, too, has been suspected and diagnosed in not a few instances, as in Case 2, where further observation and examination proved a dislocated kidney to be the cause of the grave symptoms. The pain in the region of the pylorus, increased by food, the sickness, emaciation, and the icteric tint of the skin make the diagnosis of malignant disease, and especially in a patient aged about 40 vears, a very natural one. Dr. Herbert Bramwell of Cheltenham recently published a most interesting case which ended fatally. ${ }^{1}$ A post-mortem examination in this case proved the correctness of the diagnosis and added a valuable contribution to our knowledge of the altered condition of parts which gives rise to the symptoms. In Allbutt's System of Medicine ${ }^{2}$ this altered condition of yarts is fully described. There it is stated that bands of jeritoneum produced by the dislocated kidney have been

1 Brit. Med. Jour, Oct. 19th, 1901.

2 Vol. iv, p. 346. found to cause dilatation of the stomach by mechanically obstructing the normal passage of the chyme. "Such bands may pass occasionally from the upper part of the duodenum, but they are more commonly attached to the middle or lower part of the descending portion in the position nearly opposite that at which the bile-duct enters. The drag of the peritoneum on the duodenum is probably the commonest cause of the temporary jaundice which often accompanies the gastric crisis and of the dilatation of the gall-bladder." In the light of this Case 1 is clear and so is Case 3 , which is an exact parallel to the early stage of Dr. Bramwell's case, but fortunately in my patient a short rest in bed and the wearing of a suitable pad and bandage gave complete relief from the symptoms. In the majority of cases the prominent symptoms are indigestion, pain more or less constant, and almost always increased by food, flatulence, and constipation.

The frequency with which moveable kidney is met in women as compared with men is very striking and puts it beyond doubt that there must be a cause at work in women which rarely or never acts in the male. The cases which I have met with seem to me to prove that the most common and most likely cause is tight-lacing plus muscular effort, as, for example, in cycling. One patient whose symptoms suggested malignant disease of the stomach dated the onset of her illness from a 50-mile bicycle ride and another patient of excellent physique began to suffer from the characteristic symptoms immediately after a 12-mile ride over a hilly road against time. In the case of two other female patients falls in the hunting-field were given as the probable cause. One of those two cases is interesting from the fact that for years the patient suffered from indigestion and pain in the right ilio-lumbar region, and by several gynæcologists she had been treated for "something wrong with the ovary and womb," but without benefit. This patient's right kidney lay low down and forward in the lumbar region and could easily be pressed upwards almost to the gall-bladder. The symptoms in this case were always more severe just before, and usually during, the menstrual period. "The catamenial aggravation of the characteristic sensations has been pointed out by Becquet. Lancereaux, Sawyer, and Fourrier." 3 I was able to observo this in Case 1, where with the onset of a menstrual period the kidney became distinctly enlarged and there was a threatening of a return of the gastric crisis with jaundice which accompanied a previous period. In neurotic women the symptoms are often misleading and sensations are felt in parts far removed from the offending kidney. One nervous woman complained of pain in the stomach passing up through the chest to the throat accompanied by distressing "choking sensations and terrible feelings all over the body." Her organs seemed perfectly normal, but the right kidney was freely moveable. Another woman, neurotic and anæmic, complained of occasional loss of voice and choking sensations which she associated with pain in the stomach, and the latter symptom was always increased by food. At first the abdomen was not examined, but as no relief followed the usual medicinal treatment for dyspepsia an examination was made and both kidneys were found to be freely moveable. The thin flaccid abdominal walls made palpation easy, and the kidneys were easily grasped and could be moved over a wide area. An interesting case came under my care while writing these notes. The patient, an unmarried woman, aged 37 years, consulted me on Nov. 20th and gave me a long but clear and intelligent account of years of suffering from indigestion. Two years ago, owing to her inability to take food because of the pain and sickness which it caused, she became terribly emaciated and was sent to a home to undergo the Weir-Mitchell treatment. There she improved immensely, put on weight, and was afterwards able to take a sea voyage. During the voyage, however, the symptoms returned, but they were not so severe. She is now gradually getting back to the condition she was in before undergoing the Weir-Mitchell treatment. She "cannot touch beef or mutton and can take only very small quantities of the simplest food." She was told that she was neurotic (and she knows that she is), but she is "most anxious to be able to eat food like other people." Except for a slight cardiac peculiarity this patient's organs seem perfectly healthy, but the right kidney is dislocated and lies near the upper border of the iliac region and can be pressed up almost to the gall-bladder. Of course, it is impossible 